Rok XVI (2021) | 2 (32) | S. 259-279

https://doi.org/10.12797/LV.16.2021.32.21

Mateusz Kowalski ๑

Uniwersytet Kardynała Stefana Wyszyńskiego, Warszawa

mateusz.kowalski@uksw.edu.pl

\title{
JAN BAUDOUIN DE COURTENAY, CZY HISTORIA I FILOLOGIA MOGĄ UMIEJĘTNIE ROZWIĄZAĆ SWOJE ZADANIE BEZ ŚCISŁEGO ZWIĄZKU Z FILOZOFIA,, A MIANOWICIE Z FILOZOFIĄ HISTORII I FILOZOFIĄ JĘZYKA? \\ CZ. I
}

Słowa klucze: Jan Baudouin de Courtenay, Henryk Struve, juwenilia, językoznawstwo, filozofia, filologia, historia nauki

Keywords: Jan Baudouin de Courtenay, Henry Struve, juvenilia, linguistics, philosophy, philology, history of science

Przeszukując zbiory Biblioteki Narodowej w poszukiwaniu spuścizny przedstawicieli polskiego psychologizmu lingwistycznego przełomu XIX i XX w., natknąłem się na rozprawkę młodego, wówczas dziewiętnastoletniego studenta Szkoły Głównej Warszawskiej Jana Baudouina de Courtenay. Praca datowana na 10 marca 1864 r., nosząca tytuł Czy historia i filologia moga umiejętnie rozwiązać swoje zadanie bez ścisłego zwiazku z filozofia, a mianowicie $z$ filozofia historii i filozofia języka?, jest prawdopodobnie najstarszą z poznanych dotychczas naukowych rozpraw (a właściwie juweniliów) polskiego językoznawcy. Została ona przedłożona przez Baudouina de Courtenay najprawdopodobniej jako rozprawa ćwiczeniowa przygotowana w ramach kursu filozofii i logiki prowadzonego przez dra Henryka Struvego. Liczący wówczas dwadzieścia cztery lata H. Struve w 1863 r. otrzymał stanowisko adiunkta w warszawskiej uczelni, a już w następnym roku awansował na stanowisko profesora, obejmując tym samym Katedrę Filozofii. 
Warto przypomnieć, że Struve $\mathrm{w}$ ramach działalności dydaktycznej prowadził zajęcia z filozofii, logiki, estetyki i psychologii ${ }^{1}$, na które uczęszczało wielu późniejszych wybitnych przedstawicieli polskiego pozytywizmu oraz świata nauki. Obok Baudouina de Courtenay w gronie jego słuchaczy znaleźli się Adam Antoni Kryński $^{2}$, Lucjan Malinowski ${ }^{3}$, Piotr Chmielowski ${ }^{4}$, Julian Ochorowicz ${ }^{5}$, a także literaci Adolf Dygasiński, Bolesław Prus i Henryk Sienkiewicz.

Oddana do rąk czytelnika rozprawka wydaje się tym bardziej interesująca, że na jej marginesach oraz pod ostatnią kartą rękopisu zostały naniesione czerwonym atramentem komentarze samego H. Struvego. Współtworzą one wraz z treścią pracy interesujący dialog, toczący się między wykładowcą a stawiającym swe pierwsze kroki naukowe Baudouinem de Courtenay, poświęcony metodologicznej i filozoficznej naturze języka, historii oraz filologii. Wspomniana polemika i spór naukowy wymagają oddzielnego opracowania, dlatego też nie będą w tym miejscu rozpatrywane.

Należy jednak zwrócić uwagę na to, że młodzieńcza rozprawa Baudouina wskazuje nie tylko na źródła wczesnych inspiracji naukowych, ale też na wyraźną ewolucję jego poglądów. Widoczna jest ona zarówno w rozumieniu miejsca językoznawstwa w typologii nauk, jak i w spojrzeniu na naturę samego obiektu badania naukowego oraz praw rządzących jego rozwojem.

Jak wynika z treści rozprawy, już w 1864 r. młody Baudouin de Courtenay uznawał za konieczne rozróżnienie nauk fizycznych, do których zaliczał także lingwistykę, i historycznych, wśród których znalazła się filologia. Tę ostatnią rozumiał on

1 W zbiorach Biblioteki Narodowej zachowały się rękopisy wykładów, które Struve prowadził w Szkole Głównej od roku 1863. Dowiadujemy się z nich, że obszerny wykład logiki został poprzedzony wstępem psychologicznym, na który składały się elementy nauki o bytności i pojęciu duszy (od dualizmu Kartezjusza, przez idealizm Barucha Spinozy, Immanuela Kanta i Georga Hegla, aż po realizm Johna Locke’a i Davida Hume’a), zagadnienia teorii świadomości i tzw. bezświadomości, a także uwagi o działaniu duszy, wśród których Struve objaśniał problematykę tworzenia wyobrażeń, pojęć i idei. Sama część główna wykładu z logiki zawierała elementy teorii poznania (przede wszystkim relacji podmiot poznający - przedmiot poznania), naukę o pojęciu, sądzie, wnioskowaniu, prawach logicznych, skończywszy na elementach logiki stosowanej wraz z omówieniem problematyki definiowania, argumentacji oraz podstaw metodyki badań. Tak przygotowany wykład (spisany na ponad sześciuset stronach rękopisu) dawał słuchaczom szeroki, ale też praktyczny (umożliwiający faktyczne wdrożenie w myśl naukową oraz w światopogląd) wgląd w problematykę filozoficzną.

2 Adam Antoni Kryński (1844-1932) - językoznawca, leksykograf, twórca jednego z systemów ortografii polskiej, profesor uniwersytetów we Lwowie i Warszawie, współautor Słownika języka polskiego wydawanego w latach 1900-1927.

3 Lucjan Malinowski (1983-1898) - językoznawca, dialektolog i folklorysta, profesor Uniwersytetu Jagiellońskiego.

4 Piotr Chmielowski (1848-1904) - historyk literatury, krytyk literacki i publicysta, nauczyciel i pedagog, od 1903 r. profesor Uniwersytetu Lwowskiego.

5 Julian Ochorowicz (1850-1917) - psycholog i filozof, zapoczątkował psychologiczne badania eksperymentalne w Polsce (założył niepubliczny ośrodek w Wiśle). 
jako ogólną wiedzę na temat języków i literatur narodowych. Literacką spuściznę antycznych i współczesnych mu społeczności Baudouin postrzegał jako jedną z estetycznych form ekspresji ich ducha z punktu widzenia ich historycznego rozwoju. Być może są to echa nie tylko myśli przywołanego w rozprawie Friedricha Augusta Wolfa (niemieckiego filologa uznającego język i tekst literacki za główne źródło interpretacji ludzkiej natury), ale też inspiracji filozofią Wilhelma von Humboldta ${ }^{6}$, zderzoną z późnoromantyczną myślą o duchu narodów.

Jednakże głównym kryterium metodologicznym, które skłoniło Baudouina de Courtenay do rozdzielenia nauk historycznych i fizycznych (a co za tym idzie filologii i lingwistyki), jest wolitywny charakter obiektu badania tych pierwszych. Jak czytamy w rozprawie:

Przy tej nieskończonej zmianie mowy ludzkiej działają prawa czysto naturalne, prawa fizjologiczne i psychologiczne, ale bez udziału woli ludzkiej, a gdzie nie ma woli, tam nie ma historii.

Dla filologa język jest więc środkiem, medium pośredniczącym między badaczem a intepretowanym faktem, dla lingwisty natomiast jest on sam w sobie obiektem poznania. To przekonanie będzie towarzyszyło polskiemu lingwiście do końca jego naukowej działalności. W bardziej radykalnym tonie zostanie ono powtórzone w pierwszym odczycie na Uniwersytecie Dorpackim O zadaniach językoznawstwa z 1888 r., opublikowanym kilka lat później w III tomie „Prac Filologicznych”:

Filologia, tak jak rozwinęła się ona historycznie i jak ją przeważnie uprawiają jej przedstawiciele, jest uczonością, erudycją, znajomością szczegółów, nie zaś nauką, nie umiejętnością w ścisłym znaczeniu tego wyrazu, gdy tymczasem językoznawstwo jest jednolitą, ściśle określoną umiejętnością (Baudouin de Courtenay 1891: 93).

6 Baudouinowska inspiracja myślą Humboldta wyraźna jest w całym okresie jego działalności naukowej. Okazuje się jednak, że w teoretycznych pracach polskiego lingwisty filozofia Humboldta (zob. Sobotka 2019), a zwłaszcza pogląd o języku jako manifestacji ducha narodu, interpretowana była niejednoznacznie. W przedstawionej tu rozprawie duch narodu pojmowany jest w kategoriach idealistycznych. Wydaje się, że w późniejszym okresie, a na pewno od lat 80. XIX w., Baudouin de Courtenay rozumiał koncepcję Humboldta nieco odmiennie, bo w ujęciu antropocentrycznym, bliższym założeniom kantyzmu (zob. Kowalski 2016). Oczywiście polski lingwista nigdy nie odwoływał się wprost do założeń aprioryzmu królewieckiego filozofa. Podobieństwa - co do zasad ontologicznych i teoriopoznawczych - widoczne są jednak w założeniu, że język jest tworem wyłącznie psychicznym, a więc podmiotowym. Łączy się to z przekonaniem, że rzeczywistość także ma naturę antropocentryczną. Baudouin niejednokrotnie zaznaczał, że nie ma bezpośredniego wglądu w świat poszczególnych jednostek ludzkich. Język indywidualny, choć realizowany wyłącznie w społeczeństwie, jest jednym z mechanizmów kształtowania i rozumienia rzeczywistości. Jest to jednakże problem wymagający szerokiej analizy, ponieważ - co należy zaznaczyć - ontologiczny status rzeczywistości nie jest w pracach Baudouina przedstawiony w sposób spójny i jednoznaczny (zob. Kowalski 2020). 
O ile jednak stosunek Baudouina do filologii i jej miejsca w typologii nauk nie uległ znacznym przekształceniom, o tyle jego stosunek do samej lingwistyki zmienił się zasadniczo. Już z początkiem lat 70. XIX w. Baudouin de Courtenay w sposób wyraźnie odmienny od tego z przedłożonej rozprawy zapatrywał się na kwestię praw językowych (praw głosowych). Z ujęcia czysto obiektywistycznego i fizykalistycznego uczony przeniósł pojęcie prawa językowego na grunt psychologiczny. Pozostając w przekonaniu, że zadaniem lingwistyki jest objaśnianie faktów oraz praw rządzących życiem języka, samo pojęcie faktu oraz prawa językowego Baudouin uznał za wynik podmiotowej interpretacji rzeczywistości, za jeden z mechanizmów uogólniania i oglądu przedmiotu doświadczenia:

Zarówno prawa, jak i siły to nie istoty, nawet nie fakty, ale produkty działań umysłu człowieka, służące uogólnieniu i łączeniu faktów i znalezieniu dla nich ogólnych [sic!] wyrażenia, ogólnej formuły. Nie są to demoniczne idee polecane przez filozofów wiadomego kierunku, ale pojęcia rodzajowe (Artbegriffe), tym doskonalsze, im więcej zjawisk można nimi objąć. Z innej strony te prawa i siły, jak wszelkie pojęcia i kategorie umysłowe, nie są jednolite w swym składzie, ale okazują się wypadkowymi niezliczonego mnóstwa łączących się ze sobą wyobrażeń i pojęć (Baudouin de Courtenay 2016b: 117).

Stąd już tylko krok do uznania lingwistyki za naukę stricte psychologiczną, a następnie - przynajmniej od końca lat 8o. XIX w. - psychologiczno-socjologiczną (na co niemały wpływ mógł mieć między innymi Ludwik Gumplowicz ${ }^{7}$ ). Pogląd o przynależności lingwistyki do nauk przyrodniczych i fizycznych został więc przez Baudouina ostatecznie odrzucony i niejednokrotnie poddany krytyce:

Szumnobrzmiący frazes o „organizmie języka” [...] uległ niweczącej krytyce Steinthala [...]. Ten sam frazes, odegrzany przez Augusta Schleichera, wychodzącego z założenia, że językoznawstwo jest nauką przyrodniczą, i zgodnie z tym twierdzącego, że języki są organizmami, musiał się rozwiać wobec tej prostej uwagi, że nie może istnieć niezależnie od człowieka, że, co więcej, język, jako język, fizycznie wcale nie istnieje, i że podstawa ciągłości indywidualnej języka jest wyłącznie psychiczna (Baudouin de Courtenay 1974: 159).

Samo pojęcie praw głosowych Baudouin de Courtenay uznał z czasem za jedno z tych, które powinny zostać wyrugowane z obszaru lingwistyki i zastąpione ekwiwalentem psychologicznym.

Zmiana paradygmatu lingwistycznego wpłynęła wyraźnie na stosunek badacza do problemu ewolucji języka. W swej młodzieńczej pracy Baudouin uznał, że

7 Ludwik Gumplowicz (1838-1909) - socjolog i prawnik. W swojej teorii socjologicznej zakładał istnienie zjawisk społeczno-duchowych (dziś powiedzielibyśmy: psychospołecznych), które kształtowane są $\mathrm{w}$ wyniku organizacji i działań zbiorowości ludzkich - jednym z powyższych zjawisk był w koncepcji Gumplowicza język. 
o zmianach historycznych możemy mówić jedynie w przypadku tych nauk, które za obiekt badania uznają wytwory ludzkiego ducha, językowi natomiast - podobnie jak innym wytworom świata natury - przysługuje wyłącznie wzrost naturalny. Mówienie o historii mowy ludzkiej jest bowiem wynikiem pomieszania pojęć, które po dogłębnej analizie danych językowych lingwista powinien odrzucić. Tu również uwidacznia się wskazany postulat Baudouina, w świetle którego przedmiot nauk przyrodniczych (fizyki, biologii, zoologii, geologii) nie jest i nie może być poddany działaniom wolitywnym, które wpływałyby na jego stan i rozwój w czasie. Tak jak nie sposób zmienić obiegu krwi w organizmach zwierząt, tak nie ma możliwości świadomego i celowego wpływu na zmianę praw rozwoju języka.

$\mathrm{Na}$ gruncie lingwistycznego psychologizmu Baudouin wyraźnie zrewidował swoje wcześniejsze założenia. Przede wszystkim przyjął kryterium ontologiczne, przypisujące realne istnienie wyłącznie językowi indywidualnemu (konstytuowanemu w psychice konkretnej jednostki ludzkiej). Tak pojmowany język ulega ciągłemu rozwojowi w czasie, a granice tego rozwoju wyznacza życie ludzkie. $\mathrm{Z}$ tego powodu rozwój nie może przysługiwać językowi ogólnemu, jako że jest on jedynie naukowym uogólnieniem (a w potocznym doświadczeniu - hipostazą). Dlatego też język ogólny, w myśl późniejszych poglądów Baudouina, najobszerniej wyłożonych w Zarysie historii języka polskiego z 1922 r. (zob. Baudouin de Courtenay 1983), może być rozpatrywany tylko z punktu widzenia swojej historii. Historia nie może być jednak traktowana jako ontologiczny tryb temporalnego istnienia języka, ale jako sposób jego naukowego oglądu (ma zatem charakter epistemologiczny) ${ }^{8}$.

Młodzieńcza rozprawa Baudouina de Courtenay otwiera przed badaczami jego spuścizny o wiele szersze niż $\mathrm{w}$ przedstawionym przeze mnie zarysie spektrum rozważań i dalszych analiz. Szczególnie inspirujący wydaje mi się wątek nagłej, jak widać, zmiany metodologicznego sposobu myślenia. Zwrot ku psychologizmowi (którego zapowiedzi trudno dopatrywać się w młodzieńczej pracy - mimo żywego zainteresowania myślą W. von Humboldta i Heymanna Steinthala) dokonał się na przełomie lat 6o. i 7o. XIX w. i bardzo mocno wpłynął na polską, rosyjską, a nawet europejską lingwistykę przełomu wieków9 9

8 Na temat wyróżnionych przez Baudouina de Courtenay temporalnych trybów istnienia języka indywidualnego i ogólnego piszę szeroko w pracy Język i czas. Studium myśli naukowej Jana Baudouina de Courtenay i Ferdinanda de Saussure'a (Kowalski 2016).

9 Warto przypomnieć nazwiska zarówno uczniów Baudouina, jak i językoznawców pozostających pod bezpośrednim wpływem jego lingwistycznych poglądów - mam tu na myśli przede wszystkim Mikołaja Kruszewskiego, Karola Appla (który rozwinął myśl Baudouina w kierunku neokantyzmu i fikcjonalizmu), Jana Michała Rozwadowskiego, Henryka Ułaszyna, Stanisława Szobera, Lwa Szczerbę, Siergieja Bulicza, Maxa Vasmera (prywatnie pierwszego męża najstarszej córki Baudouina, Cezarii Ehrenkreutz-Jędrzejewiczowej, światowej sławy etnografki). Nie sposób nie wspomnieć też o wpływach Baudouina na poglądy naukowe Ferdinanda de Saussure’a, a także Romana Jakobsona i innych przedstawicieli praskiej szkoły lingwistycznej. 
W przedłożonej edycji rozprawy, spisanej czarnym atramentem na 61 kartach formatu $\mathrm{A}$, ortografia i interpunkcja zostały zmodernizowane zgodnie z zaleceniami instrukcji Ireneusza Ihnatowicza (1962). Modernizacja dotyczy przede wszystkim:

1) rezygnacji z oznaczeń samogłosek pochylonych;

2) uwspółcześnienia zapisu form pochodzenia greckiego (typu: methoda, theorija) oraz łacińskiego (typu: induktivna, klassifikaciji, lingwistiki etc.);

3) ujednolicenia zapisu wielkich i małych liter w nazwach dyscyplin naukowych;

4) uwspółcześnienia zapisu ortograficznego form czasownikowych typu: módz, pomódz, ledz, uledz;

5) dostosowania do dzisiejszych zasad ortograficznych pisowni łącznej i rozłącznej wyrazów;

6) uwspółcześnienia interpunkcji;

7) rozwinięcia skrótów;

8) rezygnacji z obecnych w podsumowującej rozprawę części Tezy (karta 61) podkreśleń nazw dyscyplin naukowych (np. Filozofija języka, Psychologiji ludów, Lingwistika).

Fragmenty nieczytelne lub zniszczone zostały zaznaczone pustym nawiasem kwadratowym, natomiast formy rekonstruowane lub niejasne zostały wpisane w nawias kwadratowy. Ponadto w edycji zostały zachowane oryginalne formy fleksyjne, również tam, gdzie pojawiały się one niekonsekwentnie (np. przy rozróżnianiu formy narzędnika oraz miejscownika przymiotników rodzaju nijakiego -ém i męskiego -ym, -im, np.: sztucznem utworzeniu, ale sztucznym utworem, sztucznym dziełem).

Wszystkie komentarze H. Struvego naniesione przez niego na marginesach rękopisu znajdują się w przypisach końcowych i oznaczone są literami alfabetu łacińskiego.

Komentarz główny, zapisany przez recenzenta na ostatniej stronie rękopisu (karta 62), został oddany kursywą pod tekstem rozprawki Baudouina de Courtenay.

Z przyczyn redakcyjnych tekst został podzielony na dwie części. Część II ukaże się w kolejnym numerze „LingVariów”.

\section{Literatura}

Baudouin de Courtenay J., 1891, O zadaniach językoznawstwa, „Prace Filologiczne” III, S. 92-115.

Baudouin de Courtenay J., 1974, Jezykoznawstwo czyli lingwistyka w wieku XIX-ym, [w:] idem, Dzieła wybrane, t. 1, Warszawa, s. 153-175.

Baudouin de Courtenay J., 1983, Zarys historii języka polskiego, [w:] idem, Dzieła wybrane, t. 5, Warszawa, s. 99-186. 
Baudouin de Courtenay J., 2016a, Autobiogram, [w:] Materiały do dziejów polskiego językoznawstwa II. Jan Baudouin de Courtenay. Pisma mniej znane, wybór, przekład i oprac. M. Skarżyński, „Biblioteka LingVariów”, t. 21, Kraków, s. 23-58.

Baudouin de Courtenay J., 2016b, Niektóre uwagi o językoznawstwie i języku, [w:] Materiały do dziejów polskiego językoznawstwa II. Jan Baudouin de Courtenay. Pisma mniej znane, wybór, przekład i oprac. M. Skarżyński, „Biblioteka LingVariów”, t. 21, Kraków, s. $105-134$.

Baudouin de Courtenay J., 2016c, O mieszanym charakterze wszystkich języków, [w:] Materiały do dziejów polskiego językoznawstwa II. Jan Baudouin de Courtenay. Pisma mniej znane, wybór, przekład i oprac. M. Skarżyński, „Biblioteka LingVariów”, t. 21, Kraków, s. $135-144$.

Baudouin de Courtenay J., 2016d, Językoznawstwo, [w:] Materiały do dziejów polskiego jezzyoznawstwa II. Jan Baudouin de Courtenay. Pisma mniej znane, wybór, przekład i oprac. M. Skarżyński, „Biblioteka LingVariów”, t. 21, Kraków, s. 161-194.

InNATOWICZ I., 1962, Projekt instrukcji wydawniczej dla źródeł historycznych XIX i początku XX wieku, „Studia Źródłoznawcze. Commentationes” 7, s. 99-124.

Kowalski M., 2016, Język i czas. Studium myśli naukowej Jana Baudouina de Courtenay i Ferdinanda de Saussure'a, Warszawa.

Kowalski M., 2020, Wybrane zagadnienia psychologizmu lingwistycznego Jana Baudouina de Courtenay i Karola Appla. Próba porównania, „Biuletyn Polskiego Towarzystwa Językoznawczego" LXXVI, s. 293-306, https://doi.org/10.5604/01.3001.0014.668o.

Sовотка P., 2019, Wilhelm von Humboldt a Jan Baudouin de Courtenay $i$ Ferdinand de Saussure: filozoficzne podstawy nowożytnej myśli lingwistycznej, „Linguistica Copernicana" 16, s. 27-49, https://doi.org/10.12775/LinCop.2019.002. 


\section{Rozprawa, mająca związek z kwestią jęz[yka]}

\section{CZY HISTORIA I FILOLOGIA MOGĄ UMIEJĘTNIE ${ }^{10}$ ROZWIAZZAĆ \\ SWOJE ZADANIE BEZ ŚCISŁEGO ZWIĄZKU Z FILOZOFIĄ, A MIANOWICIE Z FILOZOFIĄ HISTORII I FILOZOFIĄ JĘZYKA?}

Jeżeli tak: jakie zadanie historia i filologia samodzielnie bez pomocy filozofii rozwiązują?

Jeżeli nie: na czym polega samodzielność historii i filologii obok filozofii?

Ponieważ między podanymi do dysputacji kwestiami w rzędzie umiejętności zupełnie pominiętą została umiejętność języka, jako samodzielna nauka, przeto czuję się w obowiązku wystąpić w obronie jej samodzielności, w obronie jej samoistności.

Nasamprzód oświadczyć muszęa , że lingwistyki żadną miarą mięszać nie można z historią, jak to słusznie czynimy z filologią, i że przeto filozofia języka, służąca tamtej za podstawę, stanąć w żaden sposób nie może obok filozofii historii.

Wiadomo, że cały w ogóle gmach wiedzy ludzkiej rozpada się na dwa wielkie działy: dział umiejętności historycznej i dział umiejętności naturalnych; tamte mają do czynienia z dzieły człowieka, te zaś z dzieły Boga; sama tylko filozofia, jako badająca ostateczne zasady wszechświata, nie da się pod żadną z tych dużych klas podciągnąć, ale je obie razem w sobie zawiera i obejmuje, obie spaja ze sobą i łączy.

Otóż twierdzimy stanowczo, że językoznawstwo, czyli filologia porównawcza, jest nauką fizyczną i metoda jej jest taką samą, jak metoda botaniki, geologii, anatomii, chemii i innych gałęzi badania natury, skutecznie jej używających ${ }^{11}$. Na próżno

$10 \mathrm{~W}$ artykule rzeczownik umiejętność występuje przede wszystkim w znaczeniu 'nauka' (np. umiejętność fizyczna, umiejętność naturalna); również przymiotnik umiejętny należy rozumieć jako 'naukowy', a przysłówek umiejętnie jako 'naukowo'.

11 W rozprawie Baudouina nie dostrzegamy jeszcze tak znamiennego dla jego późniejszych poglądów psychospołecznego sposobu myślenia o działalności językowej. Co zrozumiałe, młody badacz poszukuje dopiero własnej ścieżki rozumowania. Widoczne jest to w próbie uspójnienia podejścia do języka jako do tzw. zjawiska fizycznego (lingwistyka jako umiejętność naturalna) z teoretyczno-filozoficznym spojrzeniem Humboldta i Steinthala. Podjęte tu zadanie nie było łatwe, ponieważ obie te koncepcje znajdują się na antypodach problematyki badań nad mową ludzką. Na szereg wynikających stąd nieścisłości obecnych w rozprawie zwrócił uwagę w swoich komentarzach H. Struve. Mimo ambitnego przedsięwzięcia młody badacz nie mógł w 1864 r. stanąć na właściwym mu później polu psychospołecznym i antropocentrycznym, tak dalekim od tego, które bierze w obronę w poniższej rozprawce i które określa mianem lingwistyki jako nauki fizycznej lub naturalnej. Prawdopodobną przyczyną tego stanu rzeczy był brak odpowiedniej 
jednak oglądamy się za słusznym przyznaniem tej nauce miejsca w rzędzie nauk przyrodzonych; jedną z główniejszych przyczyn tego zjawiska może być to, że jedna z nazw tej nauce nadawanych brzmi: „filologia porównawcza”; zdawałoby się więc, że filologia porównawcza jest nauką pokrewną filologii klasycznej, a więc nauką historyczną, i że przeto metoda jej jest metodą historii, historii sztuki, prawa, polityki i religii. Nie należy się atoli łudzić tą nazwą; trudno powiedzieć, kto ją wynalazł, lecz zdaje się, że użycie jej na tym się gruntuje, iż pierwszymi rozkrzewicielami (rozumie się dla czysto filologicznych celów) byli filolodzy klasyczni. Nietrudno jednak dowieść, że choć językoznawstwo wiele zawdzięcza filologii klasycznej, to przecież nie ma z nią prawie nic wspólnego i nie może być jej subordynowanym, jak to sądziła długo przesądna i konserwatywna filologia, zamieniwszy gramatykę na swoją służebnicę do wszystkich niby to celów, i przez to złożywszy całość jej z samych recept bez żadnej naukowej podstawy. Filologia uważa język za środekc; tymczasem lingwistyk [sic!] bierze go za obiekt swego poznania; należy się więc nam zastanowić nieco nad naturą tego obiektu naszej nauki.

Język nie jest sztuką, nie jest sztucznym utworem, nie jest to agregat konwencjonalnych głosów w celu udzielania sobie wzajemnie myśli, w celu pożycia społeczeńskiego; jakżeż bowiem można by się umawiać o właściwości tego lub owego dźwięku, tego lub owego wyrazu dla oddania tego lub owego pojęcia, kiedy nie było środka umówienia się, właśnie języka? Podobnie język nie jest produktem sztuki ludzkiej w tym znaczeniu [ ] ${ }^{12}$.

[...] to przynajmniej o jej zewnętrznej formie może stanowić. I w samej rzeczy, choćby lokalna różność i rozmaitość języków nie stanowiła wcale istotnego zarzutu przeciwko zaliczaniu językoznawstwa do nauk fizycznych, to przecież jednakże historyczne zmiany i przemiany, czy to w dziedzinie jednego języka, czy też w obszerniejszem zakresie pewnej familii językowej, zdają się stanowić nieprzełamaną przeszkodę, zdają się stawiać nieprzepartą zaporę do łączenia językoznawstwa z naukami fizycznymi. Każda część natury - indywidualna, jednostkowa, czy to minerał, czy to roślina, czy też zwierzę, pozostaje w swym rodzaju i gatunku od początku do końca swego istnienia (czyli, jak chcą niektórzy, bytowania) jednym i tym samym, gdy tymczasem zapewne zaledwie bardzo mało języków po przebiegu tysiąca lat może być uznanych za te same. Historyczne przekształcenia języka mogą szybciej lub powolniej następować, mają jednak miejsce we wszystkich krajach i po wszystkie czasy.

koncepcji socjologicznej, którą Baudouin de Courtenay mógłby wówczas zaadaptować na potrzeby rozwijanej przez siebie teorii (jak miało to później miejsce z koncepcją wspomnianego już Gumplowicza). Na ten pogląd, który w pełni podzielam, zwrócił moją uwagę Oleg Leszczak. Należy bowiem przypomnieć, że na pełny rozkwit światowej socjologii oraz spór indywidualistycznej koncepcji Gabriela Tarde’a z realizmem społecznym Émile’a Durkheima ówcześni badacze musieli zaczekać aż do lat 8o. i 9o. XIX w. 
Z tego wszystkiego można wnosić, że język, ponieważ w przeciwstawieniu do innych płodów natury podlega przemianom historycznym, nie da się tak traktować jak materiał innych umiejętności fizycznych. Ten zarzut zdaje się być pozornie uzasadnionym, lecz jeżeli go bliżej rozpatrzymy i rozbierzemy, przekonamy się, iż polega on tylko na zagmatwaniu wyobrażeńd. Należy bowiem starannie rozróżniać zmianę historyczną i wzrost naturalny. Sztuka, umiejętności historyczne, filozofia i religia, mają wszystkie swoję historią, język zaś przypuszcza tylko wzrost ${ }^{e}$.

Teraz nastręcza się uwaga, że jeżeli język pokazuje stały i prawidłowy proces przemiany historycznej, to nie jest $\mathrm{w}$ mocy człowieka przemianę tę przyśpieszyć lub wstrzymać. Jak nie można zmienić praw rządzących krążeniem krwi w naszem organizmie, tak też nie można zmienić praw rządzących językiem ${ }^{\mathrm{f}} \mathrm{i}$ kuć nowych wyrazów, wyrażeń lub form wedle upodobania, tj. nie w duchu języka, lecz podług własnego, choćby nawet genialnego widzimisię. A jak człowiek o tyle tylko rozkazuje naturze, o ile zna jej prawa i im się poddaje z uległością, tak też poeci i filozofowie tylko wtedy władną po mistrzowsku językiem, gdy prawa jego znają i są im posłuszni.

Język nie może być zmienionym i ulepszonym przez pojedynczego człowieka, choćby najgenialniejszego; na utworzenie języka składa się wewnętrzna, duchowa praca całego narodug. Jest to może jedna z tych szczęśliwych rzeczy ludzkich, którymi żaden despota i samodzierżec absolutnie zawładnąć nie jest w stanie.

Nie wchodząc tu w przyczyny tego wzrostu językowego, tego wiecznego mienienia się (bo to nie może wchodzić w zakres ćwiczenia o stosunku lingwistyki do filozofii, gdyż należy specjalnie do filozofii mowy), musimy to tylko przyjąć za fakt i wybić sobie z głowy wszelkie marzenia tak o mowie objawionej ${ }^{\text {h }}$, jako też o sztucznem, z potrzeb życia społeczeńskiego wynikłem, utworzeniu mowy. Przy tej nieskończonej zmianie mowy ludzkiej działają prawa czysto naturalne, prawa fizjologiczne i psychologiczne ${ }^{i}$, ale bez udziału woli ludzkiej, a gdzie nie ma woli, tam nie ma historiij. I ta przemiana stanu językowego może być tak nagłą, że pomiędzy dzikimi ludy po wymarciu jednej generacji charakter języka zupełnie zostaje zmienionym, i to jest właśnie życie języka w stanie natury, pod wpływem czysto przyrodniczym, bez żadnych ograniczeń i krępowań tego rozwoju ze strony literatury czy cywilizacji ${ }^{\mathrm{k}}$; i dlatego to takie języki, w stanie natury żyjące, są najciekawsze dla badacza mowy.

Nie można być dosyć ostrożnym w życiu rozmaitych wyrazów, które przybrały w nauce pewne określone znaczenie. Ściśle wziąwszy, nie daje się zastosować wyraz „historia” lub „wzrost” do przekształceń ustawicznie się odmieniającej powierzchni kuli ziemskiej. O „historii” mówimy tam, gdzie występują działania swobodnych, wolnych si1'; „wzrost” ściąga się do naturalnego rozwoju istot organicznych. Tymczasem mówimy także o wzroście skorupy kuli ziemskiej, o niepowstrzymanem wzroście różnych kryształów, i wiemy dobrze, co pod tym rozumiemy; w tym to właśnie znaczeniu, nie zaś jak rośnienie drzewa, jesteśmy uprawnieni ująć wzrost 
językał. Jeżeli imieniem wzrostu można oznaczyć owe modyfikacje, które w przeciągu pewnego czasu zachodzą wskutek ciągle nowych kombinacji danych stosunków, przez nieustannie nowe ich połączenia, i które to modyfikacje wyłamują się spod prawidłowego działania wolnych sił, i jeżeli podług tej definicji możemy przyjąć wzrost powłoki kuli ziemskiej, to ten sam wyraz i w tem samem znaczeniu daje się też użyć, gdy mówimy o języku, nadajemy więc sobie prawo wyłączenia umiejętności mowy (lub języka) z umiejętności historycznych i umieszczenia jej w rzędzie nauk fizycznych.

Braku pierwiastku historycznego w języku dowodzi i to, że on jest najtrwalszym atrybutem każdego narodu; instytucje narodowe lec mogą pod naciskiem silnej woli zdobywcy lub pod wpływem żywotniejszej i pełniejszą treścią cieszącej się cywilizacji; stosunki zewnętrzne polityczne podobnie łatwo ulec mogą zmianie; nawet zwyczaje i obyczaje narodu skazić może cudzoziemszczyzna; język tylko wszystkie te burze stale przetrwać jest w stanie, dopóki dopiero zwykle naturalna śmierć nań nie przyjdzie; mogą się wprawdzie chcieć wyrzec ojczystego języka klasy ucywilizowane arcyprzemądrzałe $^{\mathrm{m}}$, lecz zarzucić go zupełnie nigdy niepodobna. Język właśnie dlatego zachowuje z jak największą wytrwałością swoję indywidualność, że nie posiada tak wyraźniej świadomości o swojem osobnem, indywidualnem charakterze, jak to $\mathrm{w}$ innych organach życia narodowego ma miejsce. Twórcza energia życia lingwistycznego każdej mowy sprowadza także z czasem niektóre organiczne zmiany, ale dzieje się tak nie po ukazu ${ }^{13}$ [sic!] gramatyków (gramatykarzy, albo jeszcze inaczej wedle Żochowskiego ${ }^{14}$, mówników), ale niepostrzeżenie, idzie w ślad za postępem i oświatą narodun.

Jeszcze jeden zarzut pozostaje do zbicia w tej materii, a jego bliższe roztrząśnięcie pomoże nam do jaśniejszego zrozumienia właściwego, realnego charakteru języka. Wielkie periody wzrostu kuli ziemskiej, które wykryto za pomocą poszukiwań geologicznych, kończą się, ustają lub przynajmniej zbliżają się do końca w tym czasie, kiedy odkrywamy pierwsze ślady życia ludzkiego i skoro historia człowieka w najobszerniejszem tego słowa znaczeniu się rozpoczyna. Periody wzrostu języka przeciwnie, rozpoczynają się naraz z historią ludzkości i biegną z nią równolegle ${ }^{\circ}$. Utrzymywano przeto, że chociaż język może być niekoniecznie dziełem sztucznym, to jednak byłoby niemożliwym zrozumieć życie i wzrost jakiego języka bez historycznej znajomości czasów, w których ten język się tworzył. Musimy, jak mówią, wiedzieć, czy język, który za pomocą drobnowidza ${ }^{15}$ gramatyki porównawczej ma być analizowanym, wyrósł dziko, wpośród nieokrzesanych plemion bez żadnej

13 Z ros. по указу 'mоса̨ rozporządzenia, dekretem'.

14 Mowa tu o Feliksie Żochowskim (1802-1868), gramatykopisarzu i encyklopedyście, autorze prac Części mowy odmieniające się przez przypadki z roku 1838 oraz Mownia języka polskiego $\mathrm{z}$ roku 1852.

Dawne określenie mikroskopu. 
literatury albo czy on przez poetów, kapłanów i mówców został wytwornie obrobionym, tj. czy został napiętnowany znamieniem epoki klasycznej. Znowu tylko z roczników historii politycznej możemy się nauczyć, czy język stykał się z drugim, jak długo trwało to zetknięcie, który z dwu ludów stał wyżej duchowo, pod względem cywilizacji, który zwyciężył, który został zwyciężonym, który z nich zaprowadził prawo, religią i sztuki krajowe i wydał największą liczbę narodowych nauczycieli, ludowych poetów i demagogów. Wszystkie te pytania noszą czysto historyczny charakter i umiejętność, która tak dużo czerpie ze źródeł historycznych, wyglądałaby tylko jako anomalia w rzędzie nauk fizycznych.

Odpowiemy na to, że między umiejętnościami fizycznymi żadna wprawdzie nie łączy się tak ściśle z historią ludzkości, jak umiejętność języka. Ależ w podobnem związku z historią, chociaż może mniejszem, stoją i inne umiejętności fizyczne (zoologia, etnologia, botanika) ${ }^{16}$. Jeżeli więc i historia języka stoi w ścisłem związku z historią człowieka, to jednak jeszcze nie mamy powodu wykluczać językoznawstwa z rzędu umiejętności fizycznych. Przy tym, chociaż rzeczywiście językoznawstwo dużo może czerpać $\mathrm{z}$ historii, to jednak nigdy to nie przekracza granic pomocniczości i nikt się dopatrzyć nie jest tu w stanie przewagi pierwiastku historycznego. Idziemy jednak dalej i twierdzimy, że językoznawstwo, jeżeli je dość prawdziwie definiujemy, może być uważanym za zupełnie niezawisłe od historii. Historia bowiem mówi o narodach jako występujących na widownią wypadków politycznych i tylko o tyle zasługuje naród na uwzględnienie w historii, o ile czyny swymi oddziaływa na postęp ogólny i oświatę całej ludzkościp; językoznawstwo zaś zapatruje się na tę kwestią ze swego stanowiska, ono zna o tyle różne ludy, o ile te różnymi mówią językami; dla niego równouprawnione są języki groźnych Rzymian, jak i tak bardzo zwykle upośledzanych Etrusków lub Japygów, przeceniających się Greków, jak i też wszystkich lekceważonych dla swego nieokrzesania barbarów, dumnych Anglików $w^{\mathrm{r}}$, jak i pogardzonych Irlandczyków, ogładzonych Francuzów, jak i nieokrzesanych Bretonów, Flamandów lub Prowensalów, podbijających Rosjan, jak i podbitych Ostiaków, Kałmuków lub Samojedów; Polaków, jako też Rusinów i Litwinów, z których pierwszymi się pogardza, jako szalonymi świętojurcami, a o drugich powiada się, że to taki gruby, nieokrzesany język, mięszanina wszystkich na świecie żyjących $(! ! !)^{17}$. I choćby jeden żył jeszcze człowiek, który by pewnego zstępującego do grobu używał języka, to zawsze tu mamy język narodowy, a więc naród reprezentowany, tymczasem ze stanowiska historycznego (a także i filologicznego) o narodzie tu mowy być nie może, i nawet śmiesznością byłoby coś podobnego utrzymywać. Co więcej, narody mięszają się z sobą czy to skutkiem naturalnego zetknięcia się we swych wędrówkach, czy też skutkiem podbojów; tymczasem języki nie mięszają się

16 Jak sądzę, można tu dostrzec mieszanie pojęcia historii (historii społecznej) z pojęciem ewolucji (historii naturalnej).

Tak w oryginale. 
nigdy ${ }^{18}$ i nie ma ani jednego języka na świecie, który by można nazwać językiem mięszanym $^{\text {s }}$, który by można uważać za mechaniczny zlepek, a choćby nawet chemiczny amalgamat kilku różnych części. Naród angielski to mięszaniec par'excellence'; tymczasem język jego nosi wprawdzie na sobie ogromne ślady wpływu obcego, przechodniego, materiał nawet jego w większej połowie jest napływowym, a jednakże dusza jego ${ }^{\text {u }}$, jego organizm skłania nas do zaliczenia go w poczet języków teutońskich, z którymi jako jedna rodzina podciąga się pod ogólniejszą jednostkę, pod szczep aryjski, czyli indoeuropejski.

Tak więc należy zrobić różnicę pomiędzy historią a wzrostem. Wzrost w stosunku do języka jest niezależnym od ludzkiego humoruw, a tylko rządzą nim prawa, którym posłuszne są organa tak ludzkiej myśli, jak i ludzkiego głosu. A choć językoznawstwo ze wszystkich umiejętności fizycznych najściślej się łączy z historią polityczną, to jednak, ściśle wziąwszy, może się bez tej obcej pomocy zupełnie obejść i można klasyfikować i analizować języki bez względu na indywidua, familie, plemiona, narody lub rasy, które ich używają, czyli mówią nimi.

Przejdźmy teraz do metody.

W umiejętnościach naturalnych panuje ogólne prawo, że ony [sic!] rozpoczynają od rozczłonkowania, postępują do klasyfikacji i na koniec dostają się do teorii, czyli że metoda ich jest induktywną, a jako taka przedstawia trzy kolejno po sobie następujące stopnie: stopień empiryczny, klasyfikujący i teoretyczny; prawo to cierpieć może wiele wyjątków i często się zdarza, że filozoficzne spekulacje należące właściwie do ostatniego, czyli teoretycznego stopnia, już wiele prób pokazują, zanim jeszcze zebrano i ugrupowano konieczne dane, czyli wiadomości pozytywne. Tak np. w obu krajach, w których nasamprzód rozkwitło językoznawstwo, w Indiach i w Grecji, zarówno zbierano czysto empiryczne prawa, jak też rzucano się w rozmaite, mistyczne teorie i różne domniemania o początku i istocie mowy. Cóż rozumiemy pod empirycznym traktowaniem? Kto był pierwszym, co dla języka tego samego dokonał, co żeglarz dla gwiazd, co ogrodnik dla swoich kwiatów? Kto to był, co pierwszy w język, czyli mowę, myśl włożył? Myśl zrobienia różnicy pomiędzy imieniem a słowem ${ }^{19}$, pomiędzy artykułem (przedimkiem) a zaimkiem, pomiędzy

18 Nie sposób dziś stwierdzić, czy krytyczna uwaga H. Struvego wpłynęła bezpośrednio na poglądy Baudouina na mieszanie się języków. Faktem jest jednak, że w swych późniejszych pracach Baudouin de Courtenay jednoznacznie odrzucił przedstawiony tu pogląd, uznając go wręcz za szkodliwy dogmat głoszony nawet przez tak znakomitych lingwistów i indoeuropeistów jak Berthold Delbrück (1842-1922) czy Friedrich Karl Brugmann (1849-1919). Problem ten, wraz z uwagami krytycznymi wobec stanowiska obu przedstawicieli młodogramatyzmu, Baudouin de Courtenay przedstawia szeroko w pracy О смешанном характере всех языков, która ukazała się w tłumaczeniu Mirosława Skarżyńskiego w 21 tomie „Biblioteki LingVariów” (zob. Baudouin de Courtenay 2016c). Warto zwrócić uwagę, że w przywołanej rozprawie polski lingwista uznaje proces „mieszania się” za fundament rozwoju zarówno fizycznego, jak i psychicznego (w tym językowego). Mowa o podziale części mowy na nominalne i werbalne. 
accusativem a nominativem, activem a passivem. Kto wynalazł te określające wyrażenia i w jakiem celu zostały one wynalezione. Na tym stanowisku stali już Grecy i następnie Rzymianie, a rezultaty szkoły aleksandryńskiej służyły długo za podstawę wszystkim owym przemądrzałym gramatykom łacińskim i greckim, które nie starały się wniknąć w istotne prawa językowe, ale tylko podawały goły materiał uporządkowany jako tako w celu łatwiejszego jego sobie przyswojenia?, boć celem tych wszystkich gramatyk było jeno podać pewne recepty, którymi się kierować trzeba przy czytaniu autorów lub przy użyciu piśmiennem danego języka. To jest stopnień czysto empiryczny.

Lecz umysł ludzki nie zadawalnia się gołym zestawieniem faktów i podciągnięciem ich pod pewne z góry ustalone kategorie. On się zapytuje, zastanawia się nad formami, np. języka, skąd się te formy wzięły, dlaczego ta lub owa forma ten lub ów stosunek wyraża? Lecz na to nie znajduje dostatecznego wyjaśnienia we własnem języku, stara się więc poznać inne języki dla przekonania się, czy tam także w podobnyż sposób te same względy i stosunki się wyrażają, i dla zobaczenia, czy z porównania odpowiednich form w kilku językach nie da się coś stanowczego w tym względzie orzec. A ponieważ jest to naturalną koleją rzeczy świata tego, iż chcąc wyjaśnić twór młodszy, trzeba poznać ten, który go poprzedził, rzuca się więc człowiek do badania starszych języków ${ }^{y}$ i w samej rzeczy przekonywa się, że formy języka młodszego są tylko okaleczeniami, oszlifowaniami pełniejszych form języka starszego, co więcej, że sam materiał językowy i tu, i tam składa się z mniej więcej podobnych pierwiastków, i to doprowadza do wniosku, że musi istnieć jakaś wewnętrzna spójnia pomiędzy rodowodem obu tych języków (rozumie się, poszukiwanie to może się dziać li tylko w zakresie języków, o których bezpośredniej jednopodrugości historia nam powiada); tym sposobem języki romańskie znajdują swe wyjaśnienie w łacinie, nowogrecki w starogreckiem, języki słowiańskie w starosłowiańskiem (choć tylko jako w najstarszej siestrze, nie zaś jako w matce), niemiecki w gockiem itp.; lecz to nie wystarcza; widzimy, że łacina, grecki, starosłowiański, gocki itp. mają także formy spólne i spólny mniej więcej materiał językowy, lecz tu brak czegoś, co by spośredniczyło te formy, co by im wszystkim służyć mogło za podstawę, bo wszystkie te języki zostają do siebie w stosunku prawie współrzędności, nie ma zaś czegoś znacznie od nich starszego; - i oto przypadkiem, trafem, jakimś zrządzeniem życzliwego bóstwa sprzyjającego rozwojowi i rozkwitowi wszystkich nauk i umiejętności wpada nam w oko sanskryt; tu lubujemy się pełnością i pierwotną jeszcze symbolicznością form, nienaruszonością i wyrazistością pierwiastków językowych, a z tym wszystkim zupełnie podobnych do form i pierwiastków języków poprzednich (powyżej przytoczonych), tak że uznajemy ten język za najstarszy i w głębokiem uniesieniu w pierwszej chwili robimy go matką gockiego, łaciny, greckiego, starosłowiańskiego itd., lecz głębsze rozejrzenie się w tych językach pokazuje nam, że sanskryt nie wszędzie największą odznacza się starożytnością, że są formy pełniejsze w innych właśnie powyżej wspomnianych językach; to nas zmusza do wniosku, że ten trzy- 
dziestowieczny sanskryt nie jest jeszcze matką innych mu pokrewnych języków, ale tylko ich najstarszą siostrą; gdzie zaś ta matka? Gdzie jej szukać? Przynajmniej nie na kuli ziemskiej; przebrzmiała ona, nie zostawiwszy po sobie najmniejszego śladu. Cóż więc nam pozostaje? Oto $\mathrm{z}$ danych językowych, które mamy przed oczyma ${ }^{z}$ we wzpomnionych [sic!] językach, odtworzyć sobie, o ile można najściślej, tę pra-matkę i tak, doszedłszy indukcyjnie do źródła, starać się teraz dedukcją zstępować coraz niżej, z pokolenia w pokolenie; jeżeliśmy dobrze tę matkę wynaleźli, odtworzyli, to nas ta nowa droga nie zmyli, w tej nowej podróży językowej nie zbłąkamy się na bezdroża. Jak botanik po poznaniu szczegółowych części i cząstek rozmaitych roślin bierze się dopiero do ich klasyfikacji, tak samo i badacz języka, badacz mowy ludzkiej musi naprzód poznać części języków, zanim się zabierze do ich klasyfikowania. Tak więc otrzymamy genealogiczną familią aa , rodzinę, grupę pokrewną pewnej liczby języków ${ }^{20}$; ależ to nie wszystko, poza tą pokrewną grupą pozostaje jeszcze cały zastęp języków, które z poznaną familią nie znajdują się w związku dostatecznem. Próbujemy więc porównywać z sobą tamte języki, a tak dochodzimy znów do pewnych grup pokrewnych (rodzin, familii): semicka, tatarska itp. i tym sposobem tworzymy genealogiczną klasyfikacją języków kuli ziemskiej (jakkolwiek jest to niepraktycznym w poznawaniu języków bez literatury i ciągłym zmianom podlegających, bo tu nie może być ścisłej genealogii). Tu jest właśnie podstawa dla gramatyki porównawczej, czyli lingwistyki ${ }^{21}$. Oprócz tej genealogicznej klasyfikacji istnieje jeszcze druga, klasyfikacja morfologiczna ${ }^{22}$, zasadzająca się na stosunku, w jakiem zostają do siebie pierwiastek i ta cząstka wyrazu, która oznacza stosunek danego pojęcia do drugich, i tu są możliwe tylko trzy klasy: jednozgłoskowość, aglutynacja i flekcyjność [sic!]. Nie zbadano jeszcze dostatecznie wszystkich familii językowych; i jakkolwiek nie jest to nigdy w zupełności możliwym, to jednakże nauka jest na tej drodze i przy wytrwałości swoich zwolenników dojść kiedyś może do możebnej (możliwej) doskonałości i pod tym względem; i wtedy będzie można śmiało, decydująco wstąpić na stopień trzeci, jakkolwiek już teraz nie brakuje i tu bardzo gruntownych, bardzo głębokich i genialnych prac; i tu już wraca językoznawstwo do filozofii, godzi

20 Autor nawiązuje do teorii drzewa genealogicznego Augusta Schleichera (1821-1868) objaśniającej historyczny rozwój języków ludzkich oraz ich ewolucyjne pokrewieństwo. A. Schleicher był również jednym z pionierów rekonstrukcji języka praindoeuropejskiego.

21 Młody Baudouin, co ze względu na czas powstania rozprawy wydaje się oczywiste, pozostaje pod silnym wpływem komparatystyki lingwistycznej stworzonej przez germanistę Jacoba Grimma (1785-1863) oraz wybitnego znawcę sanskrytu Franza Boppa (1791-1867). Ten ostatni, choć wciąż mocno kładący nacisk na metodę historyczno-porównawczą w badaniach języków indoeuropejskich, nazywany jest głównym inspiratorem powstałej w latach 7o. XIX w. w Lipsku szkoły młodogramatycznej, uznającej lingwistykę za analityczną naukę o prawach językowych.

22 Chodzi o odróżnienie klasyfikacji genetycznej (dokonywanej ze względu na historyczne pochodzenie i stopień pokrewieństwa) od typologicznej (strukturalnej) języków. Baudouin powołuje się de facto na jedno - morfologiczne - kryterium badań typologicznych, w świetle którego języki świata można podzielić między innymi na fleksyjne, aglutynacyjne czy izolujące. 
się z nią w najściślejszej harmonii i prawie że identyfikuje, jak to szczególnie z bystrych prac W. Humboldta, Steinthala ${ }^{23}$ i innych kilku jasno przegląda; nauka, przez tych mężów pielęgnowana, stoi już ponad gramatyką porównawczą i nosi nazwisko „filozofii mowy”; tak poprzednia, jak i obecna umiejętność muszą się posiłkować rezultatami fizjologii, psychologii i logiki; - a następnie filozofia mowy musi uznać za pewniki wyniki gramatyki porównawczej, która znowu poddać się poniekąd winna pod to wyższe kierownictwo, bez którego zginąć może pod nawałem szczegółów, nie dobrawszy się do żadnej myśli ogólnej. Zadaniem tego trzeciego stopnia, stopnia teoretycznego, na którem to właśnie stoi filozofia mowy, jest zbadanie: początku mowy (czy od jednej czy od kilku par ród ludzki, czy od jednej, czy od kilku mów wszystkie języki pochodzą?), istoty mowy jako najtrwalszego atrybutu człowieka w przeciwstawieniu do zwierzęcia, dalej rozwój języka, wcielanie się myśli w formę językową i odwrotnie, oddziaływanie głosu (języka) na myśl, onomatopeja, w ogóle stosunek wzajemny myśli i dźwięku, i inne tym podobne, bardzo ciekawe i żywotne kwestie.

$\mathrm{Z}$ trzeciej jeszcze strony przypatrzmy się językoznawstwu, a mianowicie ze strony jego praktyczności i praktycznych z niego korzyści, i chociaż powinno to być dla umiejętności rzeczą prawie obojętną, to jednakże każdy, choćby najidealniejszy uczony wyznać musi otwarcie, że gdyby nie miał pewnej praktycznej, zewnętrznej pobudki (oprócz daleko istotniejszego wewnętrznego poczucia potrzeby pracy naukowej) do nauki, toby zapewne stracił do niej zapał, zupełnie by ostygł, i że w ogóle koniecznością jest dla rozwoju każdej umiejętności, żeby ta umiejętność zadawalniała pewne potrzeby praktyczne; bo inaczej nie znajduje ona poparcia w ogóle, a co więcej, nie znajduje ludzi, którzy by ją pielęgnować chcieli; nie mówię tu o prawdziwych apostołach i męczennikach nauki, ale też przecie na nich nie spoczywa rozwój umiejętności; oni dają jeno impuls do badania, tchnąc ducha wszechożywczego w zwykłych pracowników. Tymczasem zdaje się, że umiejętność mowy niewiele może ofiarować owej, naszym zwłaszcza czasom właściwej i bardzo usprawiedliwionej, zasadzie użyteczności. Nie może nam ona skutecznie pomóc przy uczeniu się obcych (cudzych) języków ani też nie jest zdolną utworzyć uniwersalnego języka. Poucza ona nas jeno o istocie języka, a to zdaje się wcale niedostatecznym, aby jakiejś nowej, młodocianej nauce zapewnić spółudział, spółczucie i poparcie publiczności. Jednakże mamy problemy, które, chociaż pozornie ciemnego i spekulatywnego charakteru, były wszakże w stanie wywrzeć potężny wpływ czy to na złą, czy na dobrą stronę w historii ludzkości, czyli człowieczeństwa. Ludzie walczyli przed laty za jednę ideę i za jedno słowo życie swe poświęcali; ależ niektóre problemy, które od naj-

23 Jan Baudouin de Courtenay nieczęsto przywoływał nazwiska oddziaływujących na jego myśl filozofów. Humboldt i Steinthal, którzy obok Gottfrieda Wilhelma Leibniza i Richarda Avenariusa (głównie w kwestiach metodologicznych) należą do nielicznych wyjątków, zostali również wspomniani w jego późniejszym Autobiogramie z 1897 r. (zob. Baudouin de Courtenay 2016a) oraz $\mathrm{w}$ artykule Językoznawstwo wydanym pierwotnie w 33 tomie Wielkiej encyklopedii powszechnej ilustrowanej z 1903 r. (zob. Baudouin de Courtenay 2016d). 
dawniejszych czasów aż do dnia dzisiejszego wstrząsały światem, należą całkowicie do umiejętności mowy.

Spróbujmy kilka przykładów: 1) Nieoszacowaną przysługę wyświadcza naprzód lingwistyka mitologii; albowiem dochodzi ona do tego rezultatu, że nazwy bóstw są to pierwotne nazwania przedmiotów zmysłowych konkretnych, które następnie przez abstrakcją uduchowiono, tak np. "̌́wৎ oznacza pierwotnie tylko świtanie, brzask dnia, Zev́c jeno świetnie błyszczące niebo itd.; a kwestią tę rozwiązała gramatyka porównawcza. 2) W średnich wiekach toczyła się walka pomiędzy nominalizmem a realizmem, która wzburzała kościół przez długie stulecia i na koniec utorowała drogę reformacji; a była to tylko sprzeczka o imiona, walka o naturę języka i o stosunek wyrazów do naszych pojęć z jednej strony, a z drugiej strony do rzeczywistych, czyli istotnych rzeczy świata zewnętrznego. Nazywano kacerzami tych, którzy uważali, że wyrazy, jak sprawiedliwość lub prawda, oznaczają tylko pojęcia naszego ducha, nie zaś widne przy świetle dziennem przedmioty (rzeczy). A przecież kwestia ta redukuje się na kwestią początku i istoty mowy, co rozwiązać zadaniem jest językoznawstwa.

W nowszych czasach dano lingwistyce rozstrzygać niektóre jak najzawikłańsze kwestie, czyli pytania polityczne i socjalne: „Narodowości i języki w przeciwstawieniu do dynastii i traktatów”; ten konflikt przekształcił już w części kartę Europy i mógłby ją jeszcze więcej przekształcić; w Ameryce pobudzono filologów porównawczych do dowodzenia niemożebności spólnego początku języków i ras ludzkich, aby umiejętnymi argumentami ${ }^{24}$ uzasadnić nieszczęsną teorią niewolnictwa. Nie można sobie wystawić, aby się nauka bardziej spodlić, zbezcześcić i zhańbić była w stanie, jak na tytule owego płodu literatury amerykańskiej, gdzie pomiędzy profilami różnych ras ludzkich profil małpi umyślnie za bardziej ludzki głoszono niż profil nieszczęśliwego Negra ${ }^{25}$.

A wszakżeż i propagatorowie panslawizmu centralizacyjnego starali się wszelkimi siłami przeciągać na swoję stronę badaczy języka, aby ci, zapomniawszy o historycznych przedziałach, w imię jeno jedności, a nawet tylko bliskiego podobieństwa językowego wzywali wszystkie ludy słowiańskie do dobrowolnego zlania się w jednę niekształtną i nieruchomą bryłę, surowy materiał dla zabawki swego posiadacza.

$\mathrm{W}$ ostatnich czasach problemat stanowiska człowieka pomiędzy światem materialnym a światem duchowym zajął jedno z bardzo wydatnych miejsc między problematami umiejętności naturalnych, czyli nauk przyrodzonych. Zadaniu temu wielu ze znakomitych uczonych poświęciło wszystkie swe siły, całe swoje życie, nie rozwiązawszy zaspakajająco tego zadania, a jednak kwestia ta zachowała cały powab

24 Tu w znaczeniu 'argumentami naukowymi'.

25 Prawdopodobnie Baudouin wspomina tu o pracy Josiaha Clarka Notta i George'a Gliddona Indigenous Races of the Earth z roku 1857 bądź wcześniejszej o trzy lata publikacji tych samych autorów Types of Mankind. 
świeżości i niby za pomocą odmładzającej różdżki czarodziejskiej na zawsze swą moc zachowa. Choćby państwo zwierzęce tak daleko rozciągniono, że różnica pomiędzy zwierzęciem a człowiekiem polegałaby tylko na pewnej modyfikacji mózgu, to jednak zostaje tu zawsze granica (czyli przedział), o zniszczenie, a nawet choćby wstrząśnienie której nikt jeszcze nie śmiał się pokusić - granicą tą jest mowa ${ }^{\mathrm{ab}}$. Nawet ci, co myślenie redukują tylko do pewnego rodzaju czucia, radzi nieradzi muszą przyznać, że nie ma pod słońcem ani jednego zwierzęcia, które by mówić było w stanie. Jeżeli przeto umiejętność mowy daje nam głębokie wejrzenie w istotę tej różnicy, która zgodnie ze zdaniem wszystkich zachodzi pomiędzy człowiekiem a innymi ożywionymi stworzeniami, jeżeli stawia ona niewzruszoną granicę pomiędzy człowiekiem i zwierzęciem, to może ona też w dzisiejszej chwili rościć sobie słuszne pretensje do uznania przez tych, którzy ze szczerym podziwieniem, śledząc postęp fizjologii porównawczej, uważają się jednak za obowiązanych energicznie wystąpić przeciwko miałkim teoriom materialistów i przeciwko płytkim i nieuzasadnionym ich dowodzeniom.

Tym sposobem zbiliśmy, o ile nam sił starczyło, zarzuty zaprzeczające językoznawstwu należnego miejsca w rzędzie nauk fizycznych, do którego sobie ono słusznie rości pretensje, i to tak co do: 1) przedmiotu tej nauki, który wcale nie przypuszcza w swym rozwoju historii, a jeno wzrost przyrodzony; 2) co do metody, czyli raczej co do historycznego urzeczywistnienia się tej metody ${ }^{\mathrm{ac}}$, w której nauka nasza przechodzi trzy właściwe każdej umiejętności fizycznej stopnie, tj. stopień empiryczny, kwalifikujący i teoretyczny ${ }^{\text {ad }}$, odpowiednie dziecięctwu, młodości i wiekowi męskiemu (broń Boże starości i zgrzybiałości) każdej nauki przyrodzonej; 3) na koniec postaraliśmy się nawet o obronę samodzielności językoznawstwa ze stanowiska jego praktyczności i zastosowania, co właściwie wychodzi poza zakres ściśle umiejętnego roztrząsania tego przedmiotu, chcąc go jako tako wyczerpać, nie należy i tej strony pomijać.

\section{*** \\ Komentarze H. Struvego do rozprawy J. Baudouina de Courtenay:}

a dowieść raczej!

b „Jedną z najgłówniejszych przyczyn”, że językoznawstwo do rzędu nauk fizycznych się nie zalicza, nie jest bynajmniej nazwa, lecz przede wszystkiem pogląd na sam język, na samą nazwę. Kto język, mowę, uważa za objaw ducha ludzkiego, a nie jego fizycznej natury, ten musi zaliczyć językoznawstwo do rzędu nauk duchowych historycznych. Przeciwne zdanie ustalić się może tylko na udowodnieniu, iż język, mowa jest wynikiem, objawem fizycznej, zewnętrznej natury ludzkiej.

c A zatem jest pewna wspólność pomiędzy filologią a lingwistyką przy wszelkiej różności metody badania języka; filologia klasyczna bada języki klasyczne jako objawy rozwoju i kultury duchowej; to samo zadanie ma filologia słowiańska względem języków słowiańskich, germańska względem języków germańskich itd. Lingwistyka zaś bada sam język jako taki i wszystkie jego objawy, niezawiśle od celów historycznych; ale o ile język jako taki w sobie pierwiastki duchowe zawiera, 
o tyle lingwistyka je także uwzględnić winna. Cała ta sprzeczka o stosunek filologii do lingwistyki opartą zresztą być winna na jasnym wywodzie pojęcia jednej i drugiej. Autor zaś pojęcia filologii wcale nie dotyka, lecz zdaje się z pewnem uprzedzeniem filologii się przeciwstawia, wykazując namiętnie słabe jej strony. Filologia jako taka nie odpowiada za tych, którzy jej nie pojmują, podobnie jak filozofia nie myśli się bronić przed zarzutami czynionemi półgłówkom; wszelkie zaś namiętne bicie w słabe strony obcej, a uzasadnionej umiejętności wyłączonem być winno z umiejętnego rozbioru. Umiejętność nie polega na dobrym lub złym humorze badacza, lecz na spokojnej, obiektywnej prawdzie. To przeciwko zbyt żywym „oświadczeniom”, „twierdzeniom” itp.

d Autor niestety wszelkie zdanie przeciwne zawsze tylko do wyrazów i wyrażeń redukuje, zamiast uwzględnić rzecz, treść zdania przeciwnego.

e To jest znowu twierdzenie!, a nawet twierdzenie znoszące po części zdanie objawione na poprzedzającej stronie, że język ma „historyczne zmiany i przemiany”, „, historyczne przekształcenia”.

f Jeżeli niehistoryczność języka tylko na tym ma polegać, że człowiek samowolnie zmienić nie może praw językowych, to natenczas sama historia i wszelkie umiejętności nie mają historii, bo i ich zasad człowiek samowolnie odmienić nie może. Historyczność nie polega na możności zniesienia lub odmienienia samych praw rozwoju, lecz tylko na możności odstępowania od tych praw wskutek wolności ducha. Prawa same zostają niezmienne i oddziałują nawet, gdy człowiek wskutek swej wolności od nich odstępuje. Że zaś język odstąpić może od własnej swej prawidłowości wskutek duchowej wolności, tego dowodem właśnie skażenie języka, owe kucie nowych wyrazów, wyrażeń lub form według upodobania, o czym autor sam wzmiankuje. Gdyby język nie miał historii, to by on sam siebie zepsuć by nie mógł, chyba tylko wskutek wpływów fizycznych, jak drzewo i każda istota podlegająca prawom konieczności sama siebie zepsuć nie może. Jednak język sam w sobie odstąpić może od własnych prawidłowości, jak to w epokach zepsucia językowego widziemy.

g I państwo zmienionem być nie może przez jednego człowieka, i w ogóle wszelka umiejętność i wszelkie objawy życia duchowego polegają na połączonem działaniu całej ludzkości, ale z tego wnosić nie można, by nie miały historii. Wszystko, co tylko jest wynikiem duchowej pracy, z natury rzeczy musi mieć historię, bo czas jest żywiołem ducha, a historia treścią czasu.

h Czy bez dowodów?

i Czy prawa psychologiczne są prawami czysto naturalnemi?

j Historia sama nie jest wynikiem jednostkowej woli, lecz woli ogólnej ducha ludzkiego. Podobnie i język jako „wewnętrzna i duchowa praca” ducha ludzkiego potrzebuje być wynikiem woli jednostkowej, a jednakowoż być w swej istocie historycznym, tj. zawisłym od rozwoju ducha ogólnego w ludzkości.

k Więc zawsze literatura i cywilizacja wpływają na rozwój języka. Na rozwój innych [istot fizycznych] zapewne już w ten sposób wpłynąć nie są zdolne.

1 Gdzie działa duch w różnicy od natury.

$1 \quad$ Więc język nie wzrasta nawet na zasadzie praw organicznych, lecz ma tylko wzrost podobny ciałom nieorganicznym?

m Śmierć jest aktem historycznym, istoty nieorganiczne, kryształy, kula ziemska itp. nie umierają, według tej analogii i język umierać nie powinien, lecz jak kamień przetrwać wszelkie zmiany ducha.

[Komentarz dopisany ołówkiem - M.K.:] Autor sam jest przemądrzały!!!

[Odpowiedź dopisana ołówkiem przez Baudouina - M.K.:] Podobnie też krytyk.

n Więc organiczne przynajmniej? Cóż się w ogóle dzieje w świecie umiejętnym po ukazu? I sama historia nie rozwija się po ukazu polityków, a jednakże jest i zostaje historią; więc i język może mieć historią, choćby się zmieniać nie mógł według woli gramatyków.

o Należy się zastanowić, czy ta równoległość nie jest wynikiem przyczynowego związku.

p Jest to wielkie ograniczenie historii; historia jako taka bada wszystkie objawy życia narodowego i wszystkie objawy ludzkości. I dopiero na zasadzie takiego badania krytycznego osądza, które 
fakta, jakie narody do postępu ogólnego się przyczyniły. Hunnowie, Mongołowie i inne narody mało się przyczyniły do prawdziwego postępu, [owszem] wstrzymywali go, a jednak należą do historii i są przedmiotem jej badania. To samo można powiedzieć i o językach.

r [Od tych słów zaczyna się karta 16, na której marginesie H. Struve dopisał pionowo ołówkiem komentarz; jego zapis ortograficzny oraz układ wersyfikacyjny pozostawiam w wersji oryginalnej - M.K.:]

Autor czy nie p. intuicyją

Hugo'nem się prze-

jął - same arcydowcipne

antytezy!!!

s W rzeczywistości nader dużo jest języków mięszanych, o czym każdy się przekonać może, kto zwiedza plemiona pograniczne pomiędzy narodami, np. Szlązacy, [Wolinianie], Sabaudczycy, Elzaci itp. Że umiejętność tą mięszaninę oczyszcza i w idei czystość języków zachowywa, nie ma kwestii. Ale to samo ma miejsce i co do narodów mięszanych.

$\mathrm{t} \quad$ [Komentarz spisany ołówkiem, prawdopodobnie cytat lub parafraza - M.K.:] To wielki targ, na który każdy naród coś na wystawę przyniósł (szkaradnie kradniesz!)

[Odpowiedź Baudouina, również spisana ołówkiem - M.K.:] Łżesz, bo to wcale nie kradzione.

u Więc ma duszę? Jest żywym, zależnym od ducha?

w Ta różnica co do języka bynajmniej nie została przeprowadzona, jak tego dowodem historyczne wyrażenia autora o języku.

I historia od niego jest niezależna i ma swoje prawa.

y Czy botanik, starając się poznać roślinę, musi się zwrócić ku przeszłości? A anatom czy potrzebuje wyszukać dziadów i pradziadów człowieka, aby poznać skład jego ciała? Dla nauk przyrodniczych zawsze status quo wystarcza do wszechstronnego poznania rzeczy. Wszelkie nauki zaś, które już z natury rzeczy przeszłość badać muszą, aby teraźniejszość poznać, są naukami historycznemi. Językoznawstwo do nich należy, bo bez zbadania „starych”, nieistniejących języków, tj. bez zbadania przeszłości, nie ma umiejętnej zasady. Rozwój języka następuje po sobie, jest czasowy, historyczny i dlatego do przeszłości przywiązany. Rozwój natury zaś jest przestrzeniowy; istoty naturalne nie następują po sobie, lecz istnieją obok siebie. I dlatego też zawsze w chwili teraźniejszej całą naturę poznać można; przeciwnie język w chwili teraźniejszej przedstawia tylko małą część swej treści, bo teraźniejsze formy językowe są wynikami wcześniejszych, starych, a podstawą dla nowych, nieznanych jeszcze.

z tj. nie przed oczyma, lecz tylko jako z przeszłości zachowane.

aa Dla botanika nie ma genealogii, tylko klasyfikacja. Że w języku o genealogii koniecznie mówić potrzeba, dowodem, iż w istocie swej jest historycznym.

ab Więc mowa właśnie z duchem ludzkim tak ściśle związaną jest, że stanowi nawet istotną różnicę człowieka od zwierząt. Czy taki ważny objaw ducha ludzkiego może być przedmiotem nauki fizycznej?

ac Owszem, zdaje się, że autor w gruncie rzeczy uważa język w istocie swej za historyczny, duchowy, i tylko dla jakiegoś przedwczesnego uprzedzenia tej historycznej istocie języka zaprzecza. Autor bynajmniej nie starał się nawet dowieść, iż język jest objawem czysto naturalnym, fizycznym, a prędzej uprawnionym nie jest zaliczyć językoznawstwo do nauk fizycznych. Istota niefizyczna nie może być przedmiotem badania nauki fizycznej.

ad Autor zapomina, że klasyfikacja języków w istocie jest czasową, historyczną, a nie przestrzeniową, jak klasyfikacja istot naturalnych. 


\section{Can History and Philology Competently Address Their Tasks without a Close Connection with Philosophy, Namely Philosophy of History and Philosophy of Language? \\ Abstract}

The thesis by Jan Baudouin de Courtenay published here is probably the oldest of the texts by the Polish linguist. The text was submitted in 1864 as a part of the logic and philosophy course taught at the Warsaw Main School by Henryk Struve. It clearly shows an attempt by the young researcher to embark on a scholarly path, which turns out to be far from the one Baudouin de Courtenay took later in his academic activity. The future linguist argues here in defence of linguistics as a so-called physical science (a natural skill, as he often calls it in his dissertation), thus contrasting it with philology and history. 